\title{
Kırsal Konut Şekillenmesinde Etkili Olan Faktörler Açısından Misli Ovası Konutlarının İncelenmesi
}

\author{
Factors Effecting the Design of Rural Housing: Examining Rural Houses of \\ the Misli Plain
}

\section{Serdar CEYLAN * \\ İhsan BULUT **}

\begin{abstract}
$\ddot{O}_{z:}$ Bu fenomonolojik araştırmanın amacı, konut tasarım ve eklentilerinde etkili olan faktörlerin neler olduğunu, konut ve insan arasındaki ilişki ve etkileşimin gerçek anlamını araştırmak ve anlamaya çalışmaktır. Nitel araştırma desenine uygun olarak 2013 yılında alanda gözlem yapılmış, her bir yerleşmeden örneklem konut seçilerek konutun planı incelenmiştir. Konutlar hakkındaki sayısal veriler, yerel yönetimlerden temin edilmiştir. Literatür, kurumsal veriler, alanda çekilen fotoğraflar ve çizilen konut planları ile çalışma betimsel olarak analiz edilmiştir. Ovadaki konut tipleri; kerpiç, taş, briket ve tuğla yap1 malzemeleri ile yapılmış olup, avlulu ve avlusuz, tek katlı ve çift katlı, toprak damlı ve çatılı olarak farklı mimari dokuda görülmektedir. Kırsal konutların tasarım ve planları üzerinde çevresel etmenler, kültürel unsurlar ve ekonomik faaliyetler gibi birçok faktörün etkili olduğu görülmüştür.
\end{abstract}

Anahtar Sözcükler: Kırsal Konut, Konut Tipleri, Misli Ovası, Niğde

\begin{abstract}
The aim of this phenomenological study was to determine the factors effecting types of rural housing and to understand the relationship between housing and humans. Employing qualitative research techniques, observation in the study area were made in 2013. A sample house was determined in every settlement and the plans of these houses were analyzed. The number of houses were taken from the local authorities, the municipality and the headman. The study analyzed as descriptive with data, the house plans, photographs, statistical data and institutional knowledge. These houses were constructed from various constructional materials such as: adobe, stone, red tile, and were built to different designs, with and without courtyard, a single or two stories, and soil roof. This study showed the designs and plans of rural housing were effected by environmental, cultural and economic factors in this study area.
\end{abstract}

Keywords: Rural houses, Housing Types, Misli Plain, Niğde

\section{Giriş}

İlk çağlardan beri insanın en önemli gereksinimi olan konutlar, günümüzde sadece bir barınma mekânı olmaktan çıkmış, aynı zamanda birçok fiziksel aktivitenin yer aldığı bir mekân haline gelmiştir (Rapoport 1969; Zeybekoğlu 2005). Yapılan kazılar ve araştırmalar, insanın ilk mimari faaliyet olarak kendisine ev yapmaya giriştiğini ortaya koymuştur. Yontma Taş Çağı'nda başlayan bu gelişme, daha sonra kerpicin bulunmasıyla büyük köy yerleşmelerinin kurulmasına yol açmıştır (Karpuz 1993). İnsanların ilk mimari faaliyet olarak konut yapmasında,

\footnotetext{
* Arş. Gör., Mehmet Akif Ersoy Üniversitesi, Fen-Edebiyat Fakültesi, Coğrafya Bölümü, Burdur. serdar_ceylan_51@hotmail.com

*** Prof. Dr., Akdeniz Üniversitesi, Edebiyat Fakültesi, Coğrafya Bölümü, Antalya. ihsanbulut@akdeniz.edu.tr
} 
fiziksel ve sosyo-kültürel zorunluluklar etkili olmuştur. Bu zorunluluklar; yeme, uyuma, üreme, yıkanma, dinlenme gibi temel gereksinimler; aile, kadının yeri ve mahremiyete duyulan ihtiyaçlar olarak ifade edilebilir (Rapoport 1969; Zeybeklioğlu 2005). Konut; insanın fizyolojik, sosyolojik, estetik ve ekonomik ihtiyaçlarının karşılandığı bir yapıdır (Karpuz 1993). Fiziksel anlamda bir barınağın ötesinde olan konut; sosyo-kültürel açıdan da önemli anlamlar taşımaktadır. Nitekim konut; kültürden kültüre, mekândan mekâna farkl1lıklar gösteren, birçok aktivite, gereksinim ve insan ilişkilerini ifade eden çok yönlü bir sistemdir (Zorlu \& Sağöz 2010). Yap1 olarak " $e v$ " denildiği zaman ise; duvarları, çatısı, tavanı, döşemesi bulunan, yatacak yeri, yemek yapılacak yeri olan bina (İzbırak 1992, 125) şeklinde birçok değerlendirme ve tanımlama yapılabilmektedir. Bu bağlamda yerleşme coğrafyasının önemli çalışma alanlarından birisi olan konut; yapı malzemesi, şekil ve plan bakımından mekândan mekâna değişiklik göstermesi nedeniyle coğrafyanın ilgi alanını oluşturmakta ve bu değişim beşeri coğrafya temelinde açıklanmaya çalışılmaktadır. Çevreye ve kültüre göre biçimlenen, modern çağın popüler yenilikleri karşısında sürekli gerileyen ve yok olan geleneksel konutlar, maddi kültürün en iyi yansıması olduğu için de incelemeye değerdir (Köse 2005, 160). Konutların mimari özelliklerinden inşa tarzına, kullanılan malzemeden planlarına kadar pek çok husus hakkında coğrafi yaklaşımlarda bulunmak mümkündür (Özgür 2010, 68). Nitekim coğrafyayı anlamak için bireyi anlamak, bireyi anlamak için ise onun biricik-özel dünyası ile ortaya koyduğu sanatı incelemek gerekmektedir. Nitekim bu maddi kültürel unsurlar; insanın zihin dünyasının, aşk, özlem, tutku, sevgi ve nefret gibi duygu dünyasının dışa yansıyan ürünleridir. Gelenek ve inançların şekillendirdiği yaşam tarzlarının bireyi etkilemesi ve öznenin zihnindeki mekânın bir dış yansıması olan konut mimarisi bireyi anlamada önemli bir yer tutmaktadır. Ayrıca küreselleşen dünyada kırsal ve kentsel mimarinin homojenleşerek yerele özgü doku ve kimliğinin kaybolması karş1sında, yerel mimarinin önemi ve özellikleri ön plana çıkmaktadır. Bu nedenle, bireyin ve alanda yaşayan toplumun sosyokültürel durumunun anlaşılması açısından bu saha araştırması önem arz etmektedir.

\section{Konut Tiplerini Etkileyen Faktörler}

Konutları belirli plan tiplerine ayırarak incelemek oldukça zor bir iştir. Konut planları; coğrafi bölgelere bağlı olarak değiştiği gibi, aynı bölgede farklı plan tipi ve malzeme özellikleriyle de karşılaşılmaktadır (Karpuz 1993, 5). İklim, yapı malzemesi ve teknik esaslı olarak birçok konu uzmanı (Küçükerman 1973; Kuban 1975, 192-211; Eldem 1975) çeşitli konut planları yapmaktadır (Karpuz 1993, 5). Yapılan konut planlarında, yukarıdaki etmenlerin yanı sıra, ekonomik uğraş da konutların planlarında etkili olmaktadır. Nitekim zirai faaliyetin yoğun olduğu köylerde bu faaliyet ile uğraşan ve hayvan yetiştiren köylülerin konutları birbirinden farklılık göstermektedir. Diğer bir ifadeyle, bu iki faaliyetin birisinin ağır bastığı yerleşmelerde ya da her iki ekonomik faaliyetin yapıldığı yerleşmelerde köy konutlarının planı değişmektedir (Tanoğlu 1969, 236; Avc1 1986, 67; Özgür 2010, 73-74). Konut tasarımı ve planları üzerine çeşitli disiplinlerce birçok araştırmanın yapıldığı görülmektedir (Özden 1988; Yücel 1988; Deniz 1992; Işık 1992; Zaman 1996; Ünal 1997; Hayli 2001; Kaya 2005; Yüksek 2005; Köse 2006; Korkanç 2007; Yüksek et al. 2007; Yüksek \& Esin 2008; Karakuyu 2008; Kayserili \& Altaş 2010; Özturan 2010; Akdemir \& Korkmaz 2010; Özbaşaran et al. 2011; Demirkan 2011; Ceylan 2013). Bu özgün çalışmaların her birinde birbirine oldukça yakın alanlarda bile benzerlikler kadar da farklılık ve çeşitliliğin olduğu görülmektedir.

\section{Fiziksel Faktörler}

Türkiye'de konutların yapımında kullanılan malzemelerin ve konut tiplerinin belirlenmesinde, sosyal ve ekonomik faaliyetlerin yanı sıra fiziki faktörler de etkilidir (Tunçdilek 1967). İnsan ve 
çevre arasındaki karşılıklı etkileşimin iki görünümü, çevrenin insanı etkilemesi ve insanın çevreyi etkilemesi şeklinde olmuştur (Tümertekin 1994, 25). Konutlar da yerleşmeler gibi, şekillenmeleri ve fonksiyonları açısından coğrafi çevrenin etkisini açıçca yansıtan yerleşme unsurlarıdır (Bulut 2002, 748). İklim, topografya, bitki örtüsü, yakın çevrede var olan malzeme gibi özellikler geleneksel konutların biçimlenmesinde son derece etkili çevresel faktörlerdir (Zorlu \& Sağöz 2010, 190). Nitekim konutlar, yapıldıkları yerin topografya durumuna uymakta ve şartlara göre çeşitli şekiller almaktadır (Tanoğlu 1969, 216). İlkçağlardan beri kalker, yapı malzemesi olarak, birçok yapının (tapınak, kilise, cami, hamam, saray, kervansaray vb.) zemin döşemesinde ve duvarlarında kullanılmıştır. Ayrıca kalker sahip olduğu renk ve deseninden dolayı, mimari yapıların iç ve dış cephe süslemelerinde kullanılmıştır. Son zamanlarda ise mermer ocaklarının açılmasıyla görkemli konutlar yapılmıştır. Granit, diorit ve bazalt gibi katılaşım kayaçları, sert ve dayanıklı olan gre (kumtaşı) de konut yapımında kullanılmaktadır. Kil, mil gibi maddelerin ilk yararlanma yerinin ise, kerpiç konutların inşası olduğu söylenebilir. Nitekim tarih öncesi dönemlerde kil ve killi unsurların pişirilmesi ile pişirilmiş tuğlalar elde edilmiş ve bu tuğlalar konut inşasında yapı malzemesi olarak kullanılmıştır (Tunçdilek 1985, 27-31). Ayrıca konutun bulunduğu yerin topografik durumu ve yüksekliği, evin güneş 1şınlarından faydalanması ve doğal havalandırma imkânları bakımından oldukça önemlidir. Arazinin eğim doğrultusu, güneş ışınlarının geliş açısını etkilediğinden kuzey ve güney yamaçların güneşlenme ve buna bağlı ssınma oranı değişiklik göstermektedir (Soysal 2008, 30). Bu durum, ister istemez konutun dış duvar 1sısını ve pencerelerden iç mekâna giren güneş 1şık oranını etkilediğinden, evin iç ve dış sıcaklığını etkilemektedir. Bu nedenle, konutun pencere ve kapı yönlerinin güneye bakacak şekilde düzenlenmesi, bakı faktörünün konut tasarım ve biçimi üzerindeki etkisidir. İnsanların iklim koşullarına uyma çabaları eskiden beri sürmektedir. Nitekim beşeri müdahalelerle, ancak konutların içerisi isıtılabilmekte iken, evin dışarısındaki çevrenin etkisi ağırlığını hala hissettirmektedir (Tümertekin 1994, 15). Konutun 1sıtılması, serinletilmesi, aşırı neminin giderilmesi, ışıklandırılması ve havalandırılması için gösterilen çabalar, konut içerisinde daha rahat bir ortam oluşturma ve iklim şartlarına uyma amacı gütmektedir. Bunlardan 1sıtma ve aydınlatma gibi basit ve gerekli olanlar, çok eski zamanlardan beri kişilerin kültürlerine ve olanaklarına bağlı olarak değişik şekillerde uygulanmaktadır (Dirican 1993; Ekinci \& Ozan 2006, 4). Türkiye'nin soğuk ve kar yağışlı bölgelerinde, soğuklara karşı korunma durumu ortaya çıkmış; konutların bu atmosferik şartlara karşı yapılması gerekmiştir (İzbırak 1996, 589). Türkiye'nin doğusundaki bazı köylerde görüldüğü üzere konutlar düşük s1caklık şartlarından korunabilmek için kısmen toprağa gömülmüş bir durumda inşa edilmiştir. Bu durum iklimin konutlar üzerindeki bir etkisidir (Erinç 1973, 23). Ayrıca sıcaklık yalıtımı sağlamak için, çamur harcı konut inşasında kullanılmıştır. Taş ve kerpiç gibi yapı bileşenlerinden oluşan konutların kışın sıcak, yazın ise serin bir özelliğe sahip olması, tercih edilmesinde etkili olmuştur. Ayrıca dışarıdaki soğuk havanın konut içerisine girişini önlemek için, evin giriş kısmına antre (hol) yapılması klimatik faktörlerin konut inşası üzerindeki bir etkisidir (Bulut 1988, 59). Slcaklık yalıtımı ve sıcaklık izolasyonu; soğuk dönemlerde, yani konutların 1sitılması zorunluluğu bulunan yaklaşı 165 gün içerisinde, konutların duvar, pencere, kapı, çatı ve taban döşemesi gibi bileşenlerinden kaybettiği iç mekân sıcaklığını dengede tutmak ve bu yolla konutun sıcaklık kaybının en aza indirmek için uygulanan bir tedbirdir (Doğanay 1989, 128). Kentlerin modern çok katlı binalarında yeni yeni yaygınlaşan yalıtım sistemi, kırsal yerleşmelerde çok eski tarihlerden beri uygulanmaktadır. Kerpiç konut duvarların üzerine örtülen tahtaların arasına ot, saman, dal ve kamış gibi malzemelerin konulması (Tanoğlu 1969, 227-229); duvarların kalınlığının 1 metre kadar kalın yapılması, çatının 50-60 cm kalınlığında toprak ile örtülmesi, pencerelerin az sayıda ve küçük ebatta olması (Doğanay 1989, 129) ve çift pencerelerin yapılması bunun somut birkaç örneğidir. Rüzgârın yönü, hızı ve frekansı da konut enerji tasarımı açısından oldukça önemlidir. 
Konutlarda enerji tasarrufu sağlayabilmek için, rüzgârdan doğru bir şekilde yararlanılması gerekmektedir (Soysal 2008, 34). Nitekim yaz sıcaklıklarının uzun ve bunaltıcı olduğu, şiddetli yerel rüzgârların s1k s1k estiği yerlerde, insanlar bu klimatik şartlara uyum sağlayacak bir şekilde konutlarını inşa etmektedirler (İzbırak 1996, 596). Rüzgâr; sıcak iklim yerlerinde serinletici ve buharlaşmayı giderici bir rol oynarken, soğuk iklim yerlerinde evin duvarlarından sızarak konutun iç ve dış 1sısının düşmesine neden olmaktadır (Soysal 2008, 34). Sicak yerlerde ya da sicak yaz aylarında rüzgârın serinletici etkisinden yararlanabilmek için, evlerin birbirinin rüzgârını kesmemesine dikkat edilmesi, evlerin konumlarının planlanmasında önemli bir husus oluşturmaktadır. Nitekim rüzgâr kontrol edilebildiği oranda iç mekân konforunu iyileştirmekte, serinletmekte ve nemi uzaklaştırması açısından yararlı olabilmektedir (Utkutuğ 2000; Soysal 2008, 34). Ayrıca konutun iç ve dış kapılarının hâkim rüzgâr yönüne açılmayacak şekilde ayarlanması doğal çevre şartlarına karşı alınan bir tedbirdir (Bulut 1988, 59). Yapı malzemelerinin konut içerisindeki konumu, yönü, biçimi ve bileşenleri konutların 1sı ve nem performansını etkilemektedir. Gözenekli yapı malzemelerinin içine işleyen nem, bu malzemelerin görevini yapmasını engelleyerek, 1S1 iletkenliğini artırmakta ve 1sı direncinin düşmesine neden olmaktadır. Bu durum, konut içerisine soğuğun girmesine neden olmaktadır. Bitki örtüsü ise, yapı malzemesi olarak konutun iç ve dış mekân tasarımını etkilemektedir (Soysal 2008, 35-36).

\section{Sosyokültürel Faktörler}

Konut; ait olduğu kültür ya da etnik grubun özelliklerini, yaşam biçimlerini, davranış kurallarını, çevresel tercihlerini, zaman ve mekân taksonomilerini yansıtırken, öte yandan kullanıcının özüyle ilgili imgelerini, kendini kanıtlama ve donatımı ile bireyin kişilik ve ayrıcalığını yansıtan bir olgudur (Gür 2000; Zorlu \& Sağöz 2010). Bu bağlamda, konutun biçimlenişi sadece fiziksel etkilerin ya da etkenlerin sonucu değil, tüm sosyokültürel faktörlerin bir sonucudur. Konut şekillerinde; tüm çevresel etkilerinin yanında insanın gelenek ve görenekleri, alışkanlıkları, istek ve eğilimleri, kaprisleri, toplumsal yapısı, dünya görüşü, inancı, kültürel değer ve normları konut tasarımı üzerinde etkili olan sosyal faktörlerdir. Konutu kullanan ailenin büyüklüğü, sosyoekonomik statüsü, dünya görüşü, yaşam biçimi, konutun örgütlenişini etkileyen sosyal belirleyiciler olarak siralanabilir (Tanoğlu 1969, 216; Rapoport 1969; Tolun-Denker 1977, 62; Atik \& Erdoğan 2007, 21-22; Zorlu \& Sağöz 2010, 190). Konut inşasında insan çevre şartlarının etkisinde kalmaktadır; fakat her birey; temin ettiği malzemeyi gelenek ve göreneklerine, becerisine, kültürel seviyesine ve zevkine göre kullanmaktadır. Hatta kimi yerlerde, çevre şartları ile hiçbir ilgisi olmayan konutlara bile rastlanabilmektedir (Tanoğlu 1969, 238-239). Bu bağlamda halk mimarisi; çevrenin sunduğu malzeme yanında, bulunduğu çağın teknik ve bilgi birikimini, toplumun yaşam tarzını, inanış ve gelenekleri, üretim ve tüketim biçimlerini en yalın biçimde ortaya koyan kültürel bir olgudur (Davulcu 2009, 688). Bu nedenle, konut ve konutun eklentileri (ahır, samanlık, ambar vb.) her ailenin sosyoekonomik yapısına göre çok değişik biçimde olabilmektedir. Konutun biçim değişikliğini o yerleşmede yaşayan insanların gelenek ve görenekleri, ekonomik faaliyetleri, maddi durumları ve bulundukları bölgenin coğrafi tabiatı ortaya koymaktadır (Tunçdilek 1971, 34). Konut tiplerinin incelenmesi ve sınıflandırılmasi; ekonomi, teknoloji ve iklim gibi değerlerin analizine bağlıdır. Bu nedenle fiziksel süreçlerin yanında sosyokültürel bakış açıları da göz önünde bulundurulmalıdır (Rapoport 1969; Zeybekoğlu 2005, 7). Nitekim konutlar, insanın oluşturduğu başlıca beşeri tesisler olup, insanın doğal peyzajda meydana getirdiği karakteristik unsurlardır ve bu nedenle bir medeniyetin, gelenek ve göreneklerin en somut örneklerini ortaya koymaktadır (Tanoğlu 1969, 212). Özellikle kır konutları, geçmişten günümüze yaşanan kültürel yayılmaların ve kültürel adaptasyonların tarihi belgeseli niteliğindedir (Köse 2007, 9). Kültürel bir olgu olan konut, ait olduğu toplumun kültürel etkilerinden büyük ölçüde etkilenmektedir (Rapoport 1969; Zeybekoğlu 2005, 7). Toplumsal ve tarihsel gelişim içerisinde insanların yarattık- 
ları bütün maddi ve manevi öğelerin toplamı kültür olarak nitelendirildiğinde; maddi kültür içerisine giren mimari yapıların gözle görülen (somut) ve insan emeğiyle ortaya çıkan eserler olduğu görülebilecektir (Soysal 2008, 9). Bu nedenle kırsal-kültürel peyzaj, büyük ölçüde o yerin sakinlerinin bir eseridir. Bu az (düşük) nüfuslu insan grubunun iç organizasyonu, iskânın nasıl, ne zaman ve nerede yer alacağını tayin edebilmektedir (Hutteroth 1971). Bu nedenle "Halk mimarisi"; çevrenin sunduğu malzeme yanında, bulunduğu çağın teknik ve bilgi birikimini, toplumun yaşam tarzını, inanış ve gelenekleri, üretim ve tüketim biçimlerini en yalın biçimde ortaya koyan kültürel bir olgudur (Davulcu 2009).

Kültürün ve toplumların mekânsal farklılığı ve fonksiyonları ile olan ilgisi, kültür ve kültürel etkiler noktasında coğrafyayı diğer bilimlerden ayıracak odak noktayı oluşturmaktadır (Tümertekin 1994, 67). Nitekim farklı ülke ve bölgelerdeki konut biçimleri birbiriyle karşılaştırıldığında, değişik sosyokültürel yaşam tarzını ve sosyal yapıları yansıttıkları görülmektedir. Rapoport, insanların evlerini tasarlama ve inşa etmede sergiledikleri çeşitliliğin kültürel farklılığın bir yansıması olduğunu ifade etmektedir. Nitekim konutlar ve yerleşim şekilleri, onları oluşturan kültürü ifade etmektedir (Rapoport 1969, 46-49; Zorlu \& Sağöz 2010: 190). Çok eski çağlardan beri, Anadolu'da Türk gelenek ve göreneklerinden oluşmuş, kuşaktan kuşağa aktarılmış köklü bir kültürü bulunmaktadır. Türkiye'de sayıları on binleri bulan kır yerleşmelerinde, gelenek ve görenekleri fazlaca yansıtan mimari şekilleri görmek mümkündür (İzbırak 1996, 475-496). İnsanların davranış biçimleri gibi, mimari faaliyetleri de gelenekseldir (Karpuz 1993, 1). Nitekim gurbet görmüş olmak, asker ocağında bulunmuş olmak, hayatın çeşitli yönlerini kültüre eklemektedir (İzbırak 1996, 476). Köy konutu içerisinde geçen hayat, köy yaşantısının önemli bir kısmını meydana getirmektedir. Nitekim konut içerisinde fertlerin barınma, dinlenme, yeme gibi tüm ihtiyaçlarının karşılanması, yaşlı ve çocukların bakılıp gözetilmesi, yeni neslin eğitimi ve sosyalleşmesi gerçekleşmektedir. Bu nedenle aile, sadece belirli sayıda ferdin bir araya toplanmasından çok, kendine has bir içyapısı olan sosyal bir grubu oluşturmaktadır (Saran 1984, 159).

Konuta etki eden sosyokültürel faktörler kapsamında incelenen din, insan ilişkilerini etkileyen ve düzenleyen bir olgu olup, aynı zamanda mimariyi etkileyen önemli bir faktördür. Bu özelliği ile kültür-konut ilişkisi kapsamında birçok çalışmaya konu olmuştur (Atik \& Erdoğan 2007, 22). Dinsel temelli mahremiyet (gizlilik, özellik) anlayışı, konutlarda avlu kültürünün doğmasına neden olmuştur. İslam dininde aile ve kadına verilen kutsallık, ailenin ve kadının korunması ve saklanması biçiminde olmuş ve bu durum konutun dış mimarisini şekillendirmiş̧ir. Konutun avlusu, aile ve kadının korunmasında önemli bir işlevsellik kazanmıştır. Böylece, evin yarı özel bir mekânı olan avlu içerisinde, kadın dış dünyadan ayrı tutulmuştur (Köse 2007, 22). Dinsel inançların konut mimarisine etkisi genellikle konutun şekli, planı ve iç mekânsal düzenlemesine olmaktadır. Nitekim Afrika'da dairesel ve dikdörtgen evlerin dağılımı, dine göre belirlenmektedir (Zeybekoğlu 2005, 61). Türkiye'de de özellikle kırsal konutlarda, evin banyo ve tuvalet taşının kıbleye bakmayacak şekilde ayarlanması, inanç değerlerinin iç mekân tasarımına bir örneğidir (Atik \& Erdoğan 2007, 22). Kırsal kesimde, baba öldükten sonra en büyük erkek çocuk tarafindan annenin sorumluluğunun üstlenilmesi, yaşlı ebeveynin çocukları ile birlikte oturma düşüncesi (Saran 1984, 153) gibi sosyal durumlar konutların oda sayısı ve büyüklüğünü etkilemektedir. Nitekim Anadolu'da meskene "hane", hane içerisindeki her bir odaya da "ev" denilmektedir. Birleşik ailelerde aynı çatı altında, dede/ninenin odası, büyük ağabeyin/yengenin, ortancanın ve küçügün de odaları "ev" olarak adlandırılır, her odada da asgari mahremiyeti sağlayacak, şöminevari ocaklık, yüklük, banyo, bucaklık(raf) gibi detay bölümler yer almaktadır. Genellikle oturma, karar verme, eğlenme, yas, yemek yeme gibi faaliyetler için "sofa" denilen daha büyük bir ocaklığa sahip geniş bir bölüm olan tüm kapıların kendisine açıldığı ve kendisinin de bazen kanatlı da olabilen geniş bir kapıyla avluya (bahçeye) açılan alan kullanılır. 
Kır nüfusunun eğitim seviyesinin 1950'lerden itibaren artmasıla birlikte; insanların çevreye ve oturulan mekâna bakış açısı, konutların yapı ve mimari tarzını değiştirmiştir (Saran 1984, 151). Nitekim Erci ve Bulut'un $(1999,117)$ da ifade ettiği gibi, oda duvarlarına kâğıt kaplama yapılmasının, zemine tahta parke döşenmesinin, duvarlarda plastik boya kullanılmasının, ayrı oda ve banyo isteğinin eşlerin eğitim düzeyi ile doğrudan ilişkili olduğu belirlenmiştir. Eğitimin yanı sıra, yurtdışından elde edilen bilgi ve görgüler, gurbetçilerin konuta bakış açısını değiştirmektedir. Gurbetçilerin köylerine yaptırdıkları konutların o yörenin kırsal konut mimarisine yabancı kalacak bir tasarımda inşa edildiği ve genellikle de Avrupa mimari tarzda olduğu görülmektedir (Bulut \& Ceylan 2012, 220-221).

\section{Sosyoekonomik Faktörler}

Konut biçimini geniş ölçüde açıklamak için yapılan ekonomik faaliyetin önemi büyüktür. Avcılık faaliyetlerinden tarımsal faaliyetlere ve yerleşik hayata geçmek, yani çadırdan konuta geçmek, ekonomi ile gelişen bir olgudur (Zeybekoğlu 2005, 60). Kullanılan malzeme ve iklim gibi ekonomik şartlar da köy konutlarının biçimi, büyüklügü ve planı üzerinde büyük etki yapmaktadır. Bu nedenle köy konutları doğal olduğu kadar sosyal ve ekonomik çevrenin de bir üründür (Tanoğlu 1969, 237). Nitekim ziraat bölgelerinde yer alan köy konutları, köylünün hem oturma yeri hem de atölyesidir. Köylünün toprak mülkiyeti, toprağ 1 işletme şekli, yetiştirilen ürün, beslenen hayvan gibi ekonomik ve sosyal yaşam tarzları köy konutlarını yapı ve eklenti bakımından etkilemektedir (Tanoğlu 1969, 236; Tunçdilek 1984, 28). Konutun biçimini ortaya koyan başlıca etken, evden yararlanma tarzıdır. Konutun kullanım şekli ve ihtiyaçları karşılama durumu, konutun tasarımını etkilemektedir. Nitekim meyveci, bahçeci, ekinci, hayvancı ve ormancı köylerin konut mimarilerinin birbirinden farklılık göstermesinde yapılan ekonomik uğraş etkilidir (İzbırak 1996, 590). Kırsal yerleşmelerde konutların köy yaşantısına ve köy ekonomisine uyması, ihtiyaçlara cevap verebilmesi gerekir (İzbırak 1996, 589). Her köy, hayat tarzına veya ekonomik faaliyetine göre konut şekillerini oluşturmaktadır. Köylünün evi ile tarlası, yetiştirdiği ürün ve beslediği hayvanlar arasında çok sıkı bir ilişki bulunmaktadır. Nitekim zirai faaliyetin yoğun olduğu köylerdeki konutlar ile tarım ve hayvancılığın birlikte yapıldığı köylerdeki konutlarının planı farklılık göstermektedir (Tanoğlu 1969, 212-236). Ekonomik gelişmelerin az olduğu yörelerde genellikle, konut yapımında yakın çevreden elde edilen kerpiç, taş ve ağaç gibi geleneksel yapı malzemelerinden daha fazla yararlanılmaktadır (Özav 2002, 32). Ancak insanların ekonomik düzeyleri geliştikçe bu geleneksel konutlardan ziyade modern konutların inşa edildiği görülmektedir. Ulaşım imkânlarındaki gelişmeler, çok uzak mesafelerden getirilen yapı malzemelerinin konut yapımında kullanılmasına imkân vermektedir. İnsan doğaya hâkim olduğu nispette onun etkisinden sıyrılmaktadır (Tanoğlu 1969, 217). Ekonomik gelişmişlik ve bilgi birikimi temelinde dönemin teknolojik gelişmişlik durumu da konutların biçimlenmesinde etkili olmaktadir.

\section{Yöntem}

$\mathrm{Bu}$ fenomonolojik araştırmanın amacı, konut tasarımında etkili olan faktörlerin neler olabileceğini, konut ve insan arasındaki ilişki ve etkileşimin gerçek anlamını araştırmak ve anlamaya çalışmaktır. Kırsal konutlarının biçimlenişinde etkileyen faktörler nelerdir, konut tipleri ile sosyokültürel ve sosyoekonomik durum arasında bir ilişki var mıdır, konut yapı malzemesi yakın çevrenin bir ürünü müdür? Çalışmanın temel araştırma sorularıdır. Çalışma sahası olarak, fiziksel faktörlerin etkisini görebilmek için, ova sınırı esas alınmıştır. Nitel araştırma desenine uygun olarak sahada 2013 yılında gözlemler yapılmış, her bir yerleşmeden örneklem olarak seçilen konutlar görüntülenmiş ve bu konutların planı çizilmiştir. Konutlar amaçlı örneklem tipine göre seçilmiştir. Seçilen örneklem konutun ev ve evin eklentilerini yansıtacak nitelikte olmasına dikkat edilmiştir. 
Ayrıca seçilen konutların doğal faktörleri, sosyoekonomik ve sosyokültürel faktörleri yansıtacak özellikte olmasına dikkat edilmiştir. Örneklem olarak seçilen konutlarda oturan hanelerin gelir durumu aylık gelir durumlarına göre "düşük gelirli" (1-1400 TL), "orta" (1401-2000 TL) ve "iyi" (2001+TL) olarak belirlenmiştir. Araştırma sahasındaki konutların yapı malzemelerine göre sayısal verileri, yerel yönetimlerden temin edilmiştir. Çizilen konut planları ile konutun iç ve dış yapılarının kullanımı ve fonksiyonu ortaya konularak veriler betimsel olarak analiz edilmiştir.

\section{Bulgular}

\section{Araştırma Alanına İlişkin Bulgular}

Araştırma alanı Niğde (Merkez İlçe) ve Nevşehir (Derinkuyu) il sınırları içerisindedir (Har.1). Araştırma sahası; tüf, kül, ignimbiritten oluşan volkanik formasyonların örttüğü bir ova tabanı olup, $11,0^{\circ} \mathrm{C}$ ve $336,6 \mathrm{~mm}$ yağış ile yarı kurak bir iklime sahiptir. Akarsular bakımdan zengin olmayan çalışma alanında, stepotsu türler hâkim bitki formasyonunu oluşturmaktadır. Çalışma alanında 1 ilçe merkezi (Derinkuyu), 11 belde ve 5 köy bulunmakta (Tablo 1) ve bu 17 yerleşmede toplam 50335 kişi (2012 y1li) yaşamaktadır. Araştırma sahasında yer alan yerleşmelerin arazi kullanımında

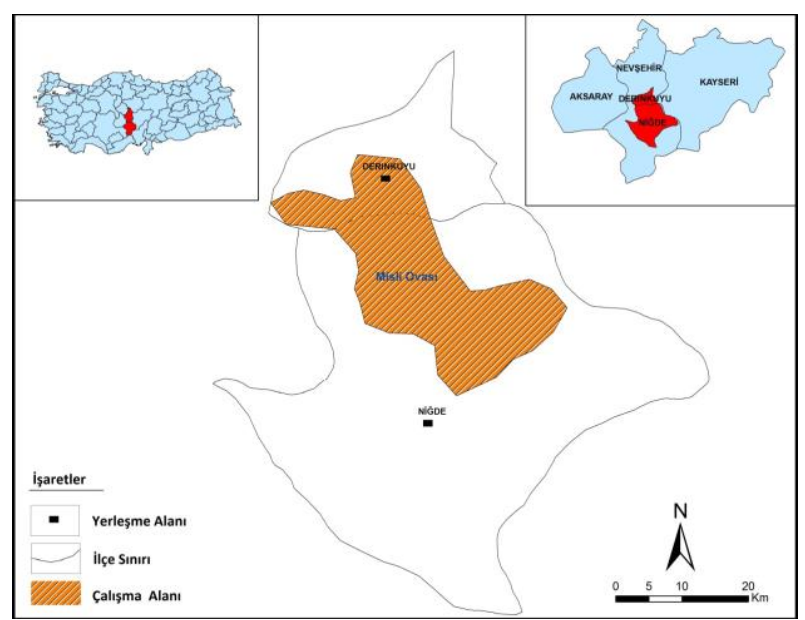

Har. 1. Araştırma Sahasının Lokasyon Haritası tarla alanları ilk sırada yer almaktadır. Toplam arazinin (1.123.028) \%45,5'i ekili dikili alanlar, \%43,8'i tarım dışı arazi ve kalan \%10,7'si ise orman ve mera arazisidir. Yerleşmelerin hâkim ekonomik faaliyeti; patates, buğday ve fasulye zirai ürün temelli tarımsal faaliyettir; ancak zirai tarımın yanında, ikincil ekonomik faaliyet olarak hayvancılık da yapılmaktadır.

Tablo 1. Yap1 Malzemesine Göre Meskenlerin Durumu (2013).

\begin{tabular}{|l|c|c|c|c|c|}
\hline Yerleşmeler & Kerpiç Ev & Taş Ev & Briket Ev & Tuğla Ev & Toplam \\
\hline Ağcaşar & 132 & 50 & - & 3 & 185 \\
\hline Alay & 334 & 141 & 190 & 95 & 760 \\
\hline Bağlama & 496 & 248 & 70 & 12 & 826 \\
\hline Çavdarlı & - & 180 & 250 & 20 & 450 \\
\hline Derinkuyu & - & 100 & 2000 & 75 & 2175 \\
\hline Hasaköy & 140 & 40 & 10 & - & 190 \\
\hline Yıldıztepe (İnli) & - & 750 & 322 & - & 1072 \\
\hline Kayırlı & - & 285 & 50 & 15 & 350 \\
\hline Kiledere & 97 & 388 & 485 & 97 & 1067 \\
\hline Konaklı & - & 2000 & 250 & 250 & 2500 \\
\hline Kömürcü & - & 171 & 40 & 2 & 213 \\
\hline Kuyutatlar & 2 & 350 & 128 & 20 & 500 \\
\hline Ovacık & - & 200 & 50 & 50 & 300 \\
\hline Suvermez & - & 759 & 150 & 40 & 949 \\
\hline Tirhan & 33 & 33 & - & - & 66 \\
\hline Yazı̈üyük & 65 & 104 & 50 & - & 219 \\
\hline Yeşilgölcük & 180 & 840 & 90 & 90 & 1200 \\
\hline Toplam & 1479 & 6639 & 4135 & 769 & 13022 \\
\hline Kaynak: Belediyele & & & & \\
\hline
\end{tabular}

Kaynak: Belediyeler, Muhtarliklar 


\section{Konutlara İlişkin Bulgular}

Araştırma sahasında yer alan konutların yüzde 51,3'ü taş, yüzde 31,6'sı briket, yüzde 11,4'ü kerpiç ve kalan yüzde 5,7'si ise tuğla yapı malzemeli olarak farklı mimari şekillerde inşa edilmiştir (Fig. 1). Ova kenarını sınırlayan Melendiz volkanik ünitesine yakın yerleşmelerde (Kayırlı, Kömürcü, Yıldıztepe), volkanik taşlar yapı malzemesi olarak konutlarda yoğun olarak kullanılmıştır (Har. 2). Ovaya yakın (Değirmenli, Uluağaç) taş ocaklarında kırılıp belirli bir şekil verilen kil taşları Çavdarlı ve Ovacık'ta konut inşasında ve konutların avlu duvarlarında yoğun olarak kullanılmıştır. Kerpiç yapı malzemeli konutlar en fazla ova ortasında yer alan Bağlama, Alay, Hasaköy, Yeşilgölcük ve Ağcaşar yerleşmelerinde; taş yapı malzemeli konutlar ise en fazla Konaklı, Suvermez ve Yıldıztepe gibi ova kenarında yer alan yerleşmelerinde görülmektedir. Konutların avlu, pencere ve kapı yönlerini çoğunlukla güney ve doğu yönlerine bakacak şekilde konumlandırılmıştır. Hâkim rüzgâr olan kuzey rüzgârlarının soğuk etkisinden korunabilmek için, kuzey yönüne büyük pencerelerden ziyade tuvalet, banyo ve mutfak için küçük pencereler yapılmıştır.

Alandaki karakteristik konut planlarının ailelerin sosyal ve ekonomik durumuna göre değiştiği görülmektedir. Bu faktörler nedeniyle konutların ve eklentilerinin yapı malzeme türü, kat sayıs1, konutun büyüklügü, oda sayısı farkl1lı göstermektedir (Fig. 312). Konutların yüzde 58,2'si tek katl1, yüzde 40'1 iki katl1, kalan \%1,8'i ise üç katlıdır. Belediyelik yerleşmelerde en fazla 2 kat ruhsatı verildiği için, beldelerde kat sayısı ikiyi geçmemektedir. İki katlı evlerin geneli, geleneksel konutlar olup, alt kat1 depo ya da ahır olarak kullanılmaktadır. Konut planı içerisinde oda, aralık, mutfak, kayıtlık, banyo ve tuvalet bulunmaktadır; ancak her konut içerisinde bu iç mekânlar görülmemektedir. Konutların yüzde 56's1 3 odal1, yüzde 24'ü 4 odalı, yüzde 18,7'si 2 odalı ve kalan yüzde 1,3 'ü ise tek odalıdır. Örtü şekillerine göre konutlar; toprak çatıl1, beton çatılı, kırmızı kiremit çatılı ve taş kemer çatılı olarak ayrılmaktadır.

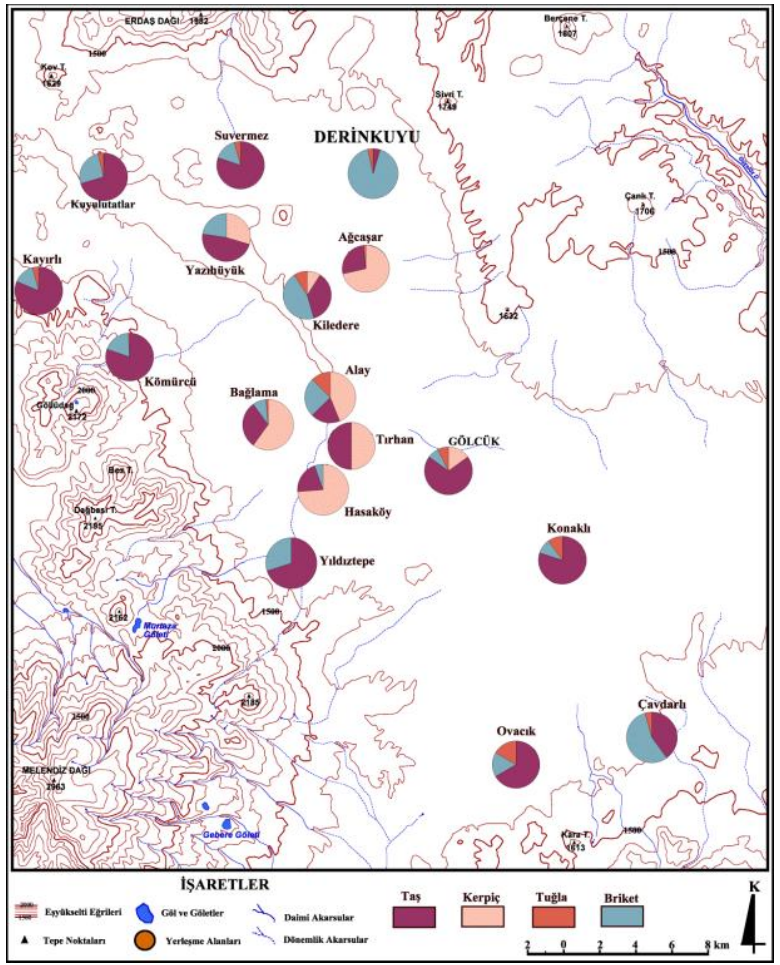

Har. 2. Araştırma Alanındaki Yerleşmelerin Konut Yap1 Malzemeleri 


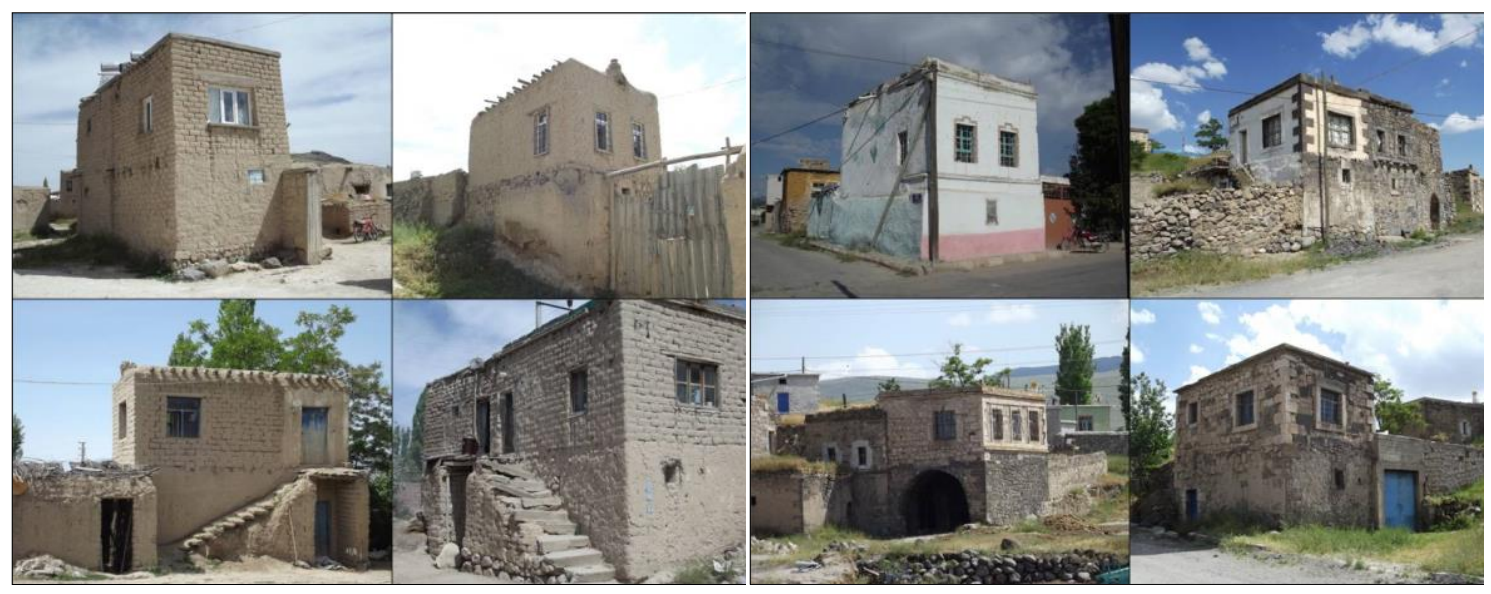

Fig. 1. Araştırma Sahasında Farklı Tasarımda Yapılmış Konut Tipleri

Araştırma alanında yoğun olarak üretilen patates, fasulye ve buğday; konutlarda patates ambarl, kiler, garaj ve depo gibi konut eklentilerinin oluşmasına neden olmuştur. Yapılan hayvancılık faaliyetleri ise, konut inşasında samanlık ve ahır gibi mekânların konut alanlarına dâhil edilmesine neden olmuştur. Ayrıca patates gibi zirai ürünlerden hasat sonrası elde edilen gelirler, modern yapı malzemeli ve planlı konutların inşa edilmesine olanak sağlamıştır.

Konut eklentisi olarak görülen tandır evleri, genellikle akraba ve komşu kadınların "imece usulü" ile yardımlaşarak birbirlerine yılda bir iki kez yufka (lavaş) ekmek yaptıkları mekânlardır. Yılın belirli dönemlerinde gün boyunca bu mekânda ekmek yapımının yanı sıra kadınlar yakın çevrelerindeki ve ailelerindeki önemli gelişmeleri anlatarak, yeme-içme, türkü söyleme, şaka yapma gibi faaliyetlerde bulunarak sosyalleşmektedir. Günümüzde köylere (somun) ekmek dışarıdan (firından) gelse de sadece sabahları bu ekmekler tüketilmekte, öğle ve akşamları tandırda yapılmış yufka ekmekler (lavaş) tüketilmektedir. Örneklem olarak seçilen konutların bazılarında "tandır evi" evin eklentilerinde yoktur. Bunun nedeni ise, ovadaki köylerin bazılarında "tandır evi" yerine evin avlusu dışına yapılmış "fırın" denilen kare planlı küçük firın ocaklarının olmasıdır. Ayrıca bazı konutlarda tandır evi, kapalı bir mekân olmamakta, evin avlusu içine 1 metre yuvarlak çukur kazılarak da ekmek pişirme olayı görülmektedir.

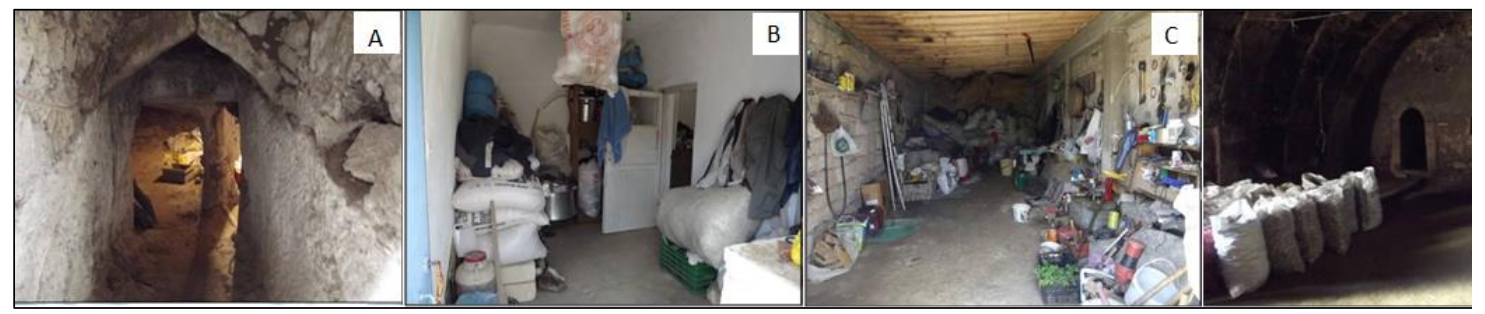

Fig. 2. Araştırma Sahasındaki Kiler (a), Kayıtlık (b), Garaj-Depo (c), Ambar (d) Görünümleri

Konutların bir eklentisi olan kayıtlık, kiler, ambar ve depo terimlerin farklı yörelerde değişik isimlerde kullanılması sınıflandırmayı zorlaştırmaktadır (Fig. 2). Araştırma sahasında görülen Garaj ve depo; zirai araç gereçlerin (traktör, pulluk, ilaçlama makinesi, patates sökme makinesi, gübreleme makinesi vb.) konulduğu bir konut eklentisidir. Garajlar alanda depo olarak da kullanılabilmekte ve çoğu depoya garaj ya da garaja depo denilebilmektedir. Kayıtlık; üretilen ve kışlık erzak olarak tüketilen (yufka ekmek, salça, elma, ceviz, kuru kayısı, kuru üzüm, pekmez, peynir, un, bulgur vb.) ürünlerin saklandığı yerdir. Kayıtlık konut içerisinde olabildiği gibi, konutun yanında bir eklenti olarak da yer alabilmektedir. Kiler ise, kaya-tüf zeminli yerlere oyulmuş mağara odasına verilen bir isimdir. Kiler, serin olduğu için, yaz aylarında adeta doğal 
bir soğuk hava deposu görevi üstlenmektedir. Araştırma sahasında yer alan bu kilerlere genelde patates konulmaktadır. Patatesler, yazın sicak ortamindan bu kilerlerde muhafaza edilmektedir. Kilerin içerisinde bulunan nemin dışarı çıkması için, kilerlerin tavan kısımlarında havalandırma delikleri bulunmaktadır. Ambar terimi, araştırma sahasında binanın temel kismına (bodrum katına) bazen de asıl evin yanında yer alan eklentilere verilen bir isimdir. Bu ev eklentileri; buğday ambarı, patates ambarı gibi içerisine konulan ürüne göre isimlendirilmektedir.

Çalışma alanında yer alan ambarların içeri-

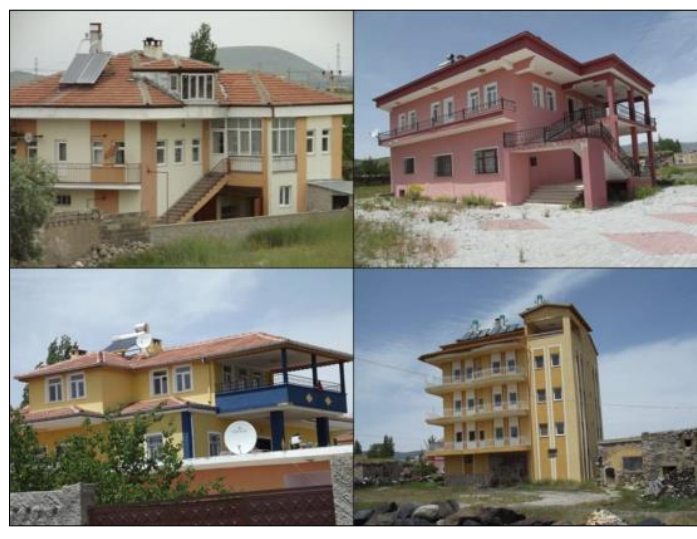

Fig. 3. Misli Ovası'nda Yer alan Köylerde Görülen Modern Yapı Malzemeli Konutlar sine genellikle patates konulmaktadır. Alandaki yerleşmelerin içerisinde ve özellikle yol kenarında yer alan konutlarda avlu duvarı ile konutların etrafının çevrili olduğu ve dış mekân karşı avlunun izole edildiği görülmüştür. Konutların demir kapı ve avlu duvarları ile çevrili olması aile mahremiyetinin yanı sıra, kendilerinin, hayvanlarının ve diğer zirai araçlarının korunmasını sağlamak amaçlı olması da etkili olmuştur. Alandaki avlusuz konutların ise, genellikle köy yerleşmesinin uzağında (dışında) yer alan münferit meskenlerde olduğu görülmektedir. Genellikle tarla kenarına yapılan bu konutların yakınında başka bir konutun olmaması ve bir yolun bulunmaması avlu duvarı inşa etmeyi gerektirmemiştir. Yerleşmelerde aynı konut içinde birden çok aile görülmese de aynı avlu içinde birkaç ailenin yaşadığı görülmektedir. Ailenin evlenen oğlunun ya da evli erkek kardeşlerin aynı avlu içinde bir arada yaşaması, çocuklarının aynı avlu içinde bir arada oyun oynayarak büyümesi, tarla sulama ve hasat gibi zirai işlerde aynı avlu içindeki aileler arasında dayanışma ve işbölümünün olması sosyokültürel bağların güçlü olduğunun bir sonucudur.

\section{Modern Yapı Malzemeli Konutlar}

Teknik, teknolojik kültür seviyesinin artmasıyla birlikte insanın çevre üzerine müdahalesi söz konusu olabilmektedir. Günümüzde insan, çevresel etkilerden en az etkilenecek bir tarzda beşeri faaliyetlerini sürdürebilmekte, yakın çevreden bağımsız bir şekilde konutlarını inşa edebilmektedir. Nitekim son dönemlerde araştırma sahasında yapılan modern meskenlerin betonarme yapıldığı görülmektedir (Fig. 3). Betonarme konutların en önemli avantaj1 yer sarsıntıs1 gibi doğa olaylarına karşı dirençli olmasıdır. Ayrıca çok katlı yapılabilmesi, 1sı yalıtımlı ve hijyenik olması diğer avantajlarını oluşturmaktadır. Toprak evlere göre, haşerelerin konut içerisinde üremesi ve yuva yapması için elverişsiz olması, konut içerisinde önemli bir yarar sağlamaktadır. Modern yapılı meskenler sahadaki hemen her yerleşmede görülebilmektedir. Yapılan modern meskenlerde; çimento, demir, kireç, kırmızı kiremit, plastik (pimapen) pencere gibi çağdaş yapı malzemelerinin kullanıldığı görülmektedir (Fig. 3).

Araştırma sahasında yer alan bazı modern meskenlerin üst katlarında balkon ve teras bulunmaktadır (Fig. 3). Konutun dış mimarisindeki bu girinti ve çıkıntılar, dışarıdan alınan kültürün yörede yapılan yeni konutlara uyarlanması ile izah edilebilir. Diğer bir ifadeyle, sanayi şehirlerine göç etmiş nüfusun ya da Avrupa gurbetçilerinin etkilendikleri kültürün kırsal kesimdeki bu konutlara birer yansimasıdır. 


\section{Taş Kemer Biçimli Konutlar}

Taş kemer çatılı konutlar, Kapadokya Bölgesi'ni oluşturan Niğde, Nevşehir ve Aksaray İli kırsal yerleşmelerinin karakteristik konut tipini oluşturmaktadır (Fig. 4). Konutların dayanıklılı̆̆ını artırmak için inşa edilen bu yapılar, bu bölgede belirli bir dönem egemen olan Hıristiyan kültürün mimari izlerini taşımaktadır. Sahada yer alan Derinkuyu, Yeşilgölcük ve Ovacık, Konaklı, Yıldıztepe ve Çavdarlı gibi birçok yerleşmede taş kemer çatılı konut ve eklentileri görülmektedir. Anadolu mimarisinin en dikkat çekici mimari şekli olan taş kemer tasarımlı bu yapılar, yöre halk mimarisinin adeta tarihi bir objesidir. Kapadokya Bölgesi’nin geniş bir kesiminde bu tasarımlı kır mimari örneklerini görebilmek mümkündür. Taş kemer çatılı bu mimari yapılar, duvarın üst kısmından yukarı doğru taşların sıkıştırılması ve yarım hilal şeklinde birbirlerine doğru yaklaştırılması sonucu inşa edilmektedir (Fig. 4).

Taş kemer çatılı konutlar, bir oturma odası olabildiği gibi; ambar, ahır gibi konutun bir eklentisi de olabilmektedir (Fig. 4). Duvar ve çatısı taştan yapılmış bu konutların yazın serin, kışın sıcak bir özellik göstermesi, kullanışlılığını ve kullanımını artırmakta; ahır gibi eklentileri içerisinde hayvan beslenmesine uygun imkân sağlamaktadır. Benzer şekilde, içerisine üretilen mahsulün çürümeden uzun süre muhafaza edilmesine de imkân vermektedir. Taş kemer çatılar, sadece evin örtü malzemesi olarak değil, aynı zamanda evin temeli ve birinci katında da kullanılmaktadır. Evlerin alt katının taş kemerli yapılmasında, konutun sağlam olmasının amaçlanması temel etken olmaktadır (Fig. 4).

\section{Örneklem Seçilen Konutlara İlişkin Bulgular}

Araştırma alandan örnek olarak seçilen konutların planları ve konut sahiplerinin ekonomik uğraşları ele alındığında, kırsal konutların şekillenmesinde rol oynayan doğal ve beşeri faktörleri görebilmek mümkündür.

Güngör'ün konutunun 1. katı ve eklentileri taş, 2. kat1 ise briket yap1 malzemesinden 1980 y1linda

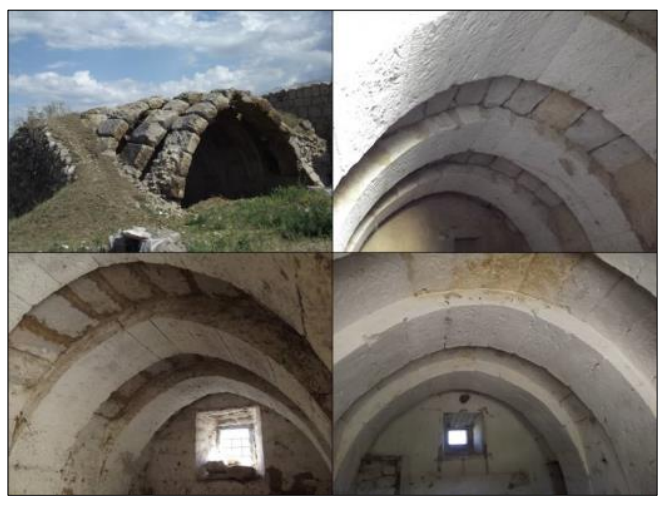

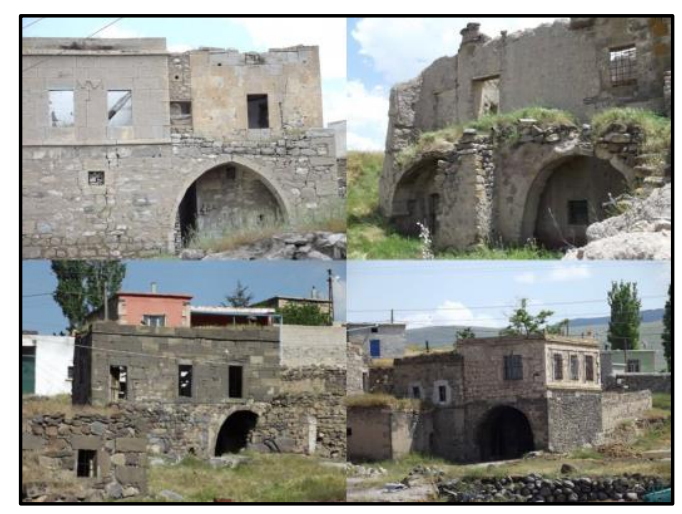

Fig. 4. Taş Kemerli Tasarımlı Konutlar inşa edilmiştir. Melendiz Dağı'nın çevreye yaydığı volkanik parçacıkların (taş-ignimbrit) varlığı, konut yapı malzemelerinde belirleyici bir faktör olmuş ve dağın yakın çevresindeki yerleşmede yer alan bu konutun da yapı malzemesini etkilemiştir. Konut sakinlerinin 1980 yılındaki ekonomik düzeyi ve modern yapı malzemesine erişilebilirlik durumunun kısıtlılığı, kendilerini yakın çevredeki malzemeyi yapı malzemesi olarak kullanmasına itmiştir. Eklentiler toprak çatılı, asıl konut ise düz beton çatılıdır (Fig. 5). Konutun ön cephesi güney ve doğuya bakmaktadır. Tandır evi, samanlık, ahır, yemlik, tezeklik konutun eklentileridir. Konutun yüksek duvar ve demir kapı ile dışarıya kapalı olması, ailenin mahremiyetinin korunması, can ve mal güvenliğinin sağlanması içindir. Konutun üst katında tek oda bulunmakta ve burası genelde uyuma ve misafir ağırlama işlevi görmektedir. Alt katta yer alan odalar gün içerisinde oturma, dinlenme ve yemek yeme amaçlı olarak kullanılmakta; mutfak, doğrudan avluya açılmaktadır. Bu nedenle mutfak, evin bir eklentisi görünümündedir (Plan 3). 


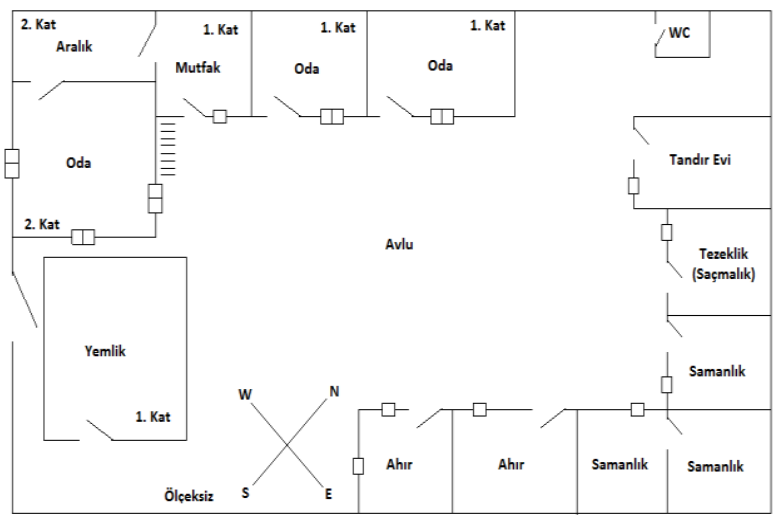

Plan 3. Murat Güngör'e Ait Ev ve Evinin Planı

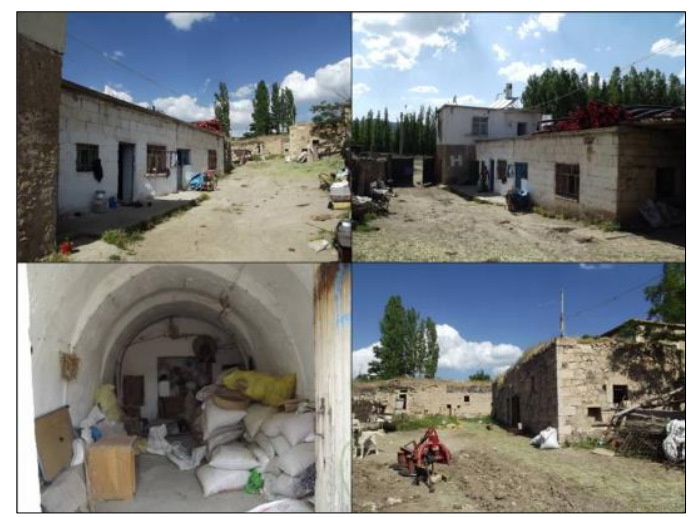

Fig. 5. Murat Güngör'ün Evi (Yıldıztepe Beldesi, Orta Gelirli)

Paşa'nın konutu ve konutun eklentileri, taş yapı malzemesi ile 1983 yılında yapılmıştır. Eklentiler düz toprak çatıl1, oturulan mekân ise beton çatılıdır (Fig. 6). Evin içerisinde 2 oda, mutfak, banyo ve tuvalet bulunmaktadır. Eklentiler ahır ve kümeslikten ibarettir. Ahırlar geçmişte hayvan barınma amaçlı olarak kullanılırken, günümüzde bu amaçta kullanılmamaktadır. Konut sahibinin çocuklarının göç etmiş, eşinin ölmüş ve kendisinin de yaşlanmış olması, daha önce ahır olarak kullanılan konut eklentilerinin günümüzde boş-atıl kalmasına neden olmuştur. Evin ön cephesi güneye bakarken, arka cephesi hâkim rüzgâr olan kuzey sektörlerine kapalı ocak şekilde inşa edilmiş olması, çevresel şartlara karşı alınmış bir tedbir olduğu göstermektedir (Plan 4).

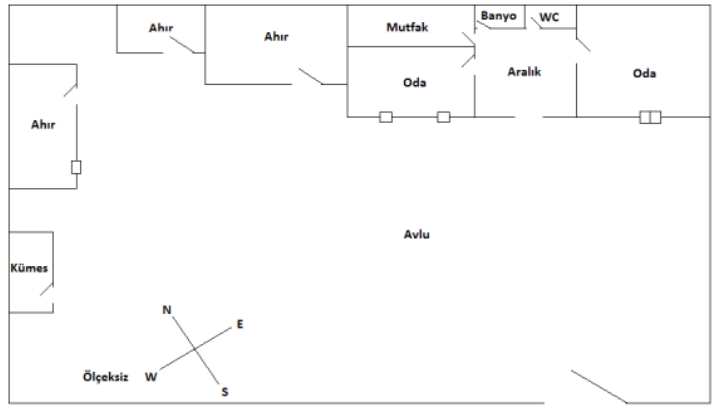

Plan 4. Mesut PAŞA’nın Evi ve Eklentilerinin Planı

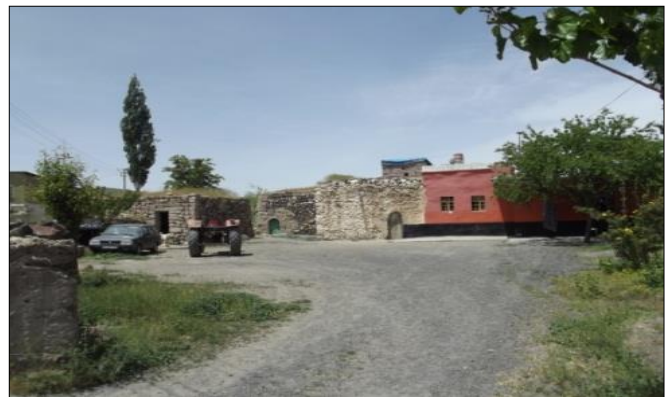

Fig. 6. Mesut PAŞA'nın Evi (Suvermez Köyü, Düşük Gelirli)

Akcan'ın konut eklentileri 1976 yılında kerpiçten, asıl konut ise 1992 yılında taştan yapılmıştır. 1976 y1lında yapılmış olan asıl konutun 1992 yılında taştan yeniden inşa edildiği görülmektedir. Eklentilerin üzeri toprak çatılı, asıl evin üzeri ise beton çatılıdır (Fig. 7). Evin ön cephesi doğuya bakmaktadır. Asıl evin yanında; garaj, depo, samanlık, ahır, tandır evi ve patates ambarı gibi konut eklentileri inşa edilmiştir (Plan 5). Bu eklentiler, tarıma ek olarak hayvancılık faaliyetiyle de uğraşıldığını bize göstermektedir. Asıl oturulan ev olan 2. kat; iki odalı olup, giriş kısmı aralığa açılmaktadır. Mutfak, evin alt katında; wc ise evin dışarısındadır. Evin avlu giriş kısmı, köyün içerisine giden asfalt yola bakmaktadır.

Karatekir'in konut ve eklentileri 1988 yılında kerpiçten yapılmıştır (Fig. 8). Oğlu ve gelinin oturduğu yer, kırmızı tuğladan inşa edilmiş olup, bir oda ve aralıktan oluşmaktadır. Ailenin evlenen erkek çocuğunun baba ocağından ayrılmadan, evin yanına inşa edilen konutta yaşaması geniş aile yapısının hala devam ettiğini göstermektedir. Yeni evlenen bu çiftin yemek yeme ve diğer ihtiyaçlarını babasının konutu içerisinde karşıladığı; uyuma, oturma ve dinlenme gereksinimlerini ise kendisine yapılan tek odalı konutta sağladığı görülmektedir. Kerpiç konutlar 
toprak çatılı, kırmızı tuğlalı konut ise beton çatılıdır. Konut ve eklentileri kuzey rüzgârlarına kapalı olup, evin ön cephesi güneye bakmaktadır. Ahır ve kömürlük dışında, farklı girişleri olan odalar dikkati çekmektedir (Plan 6).

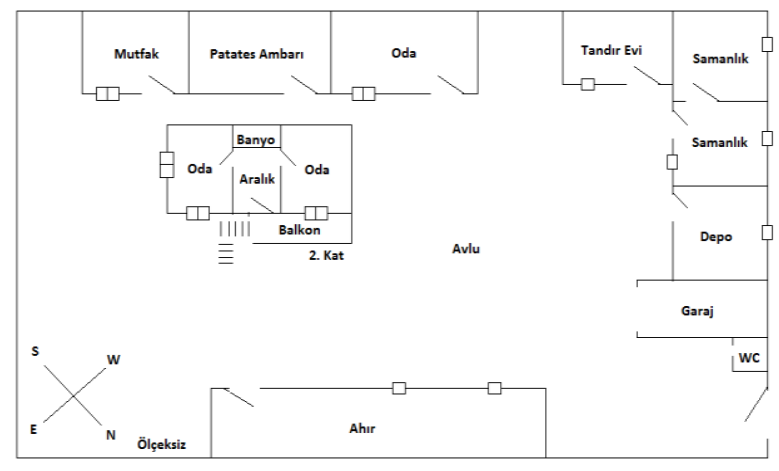

Plan 5. Ramazan AKCAN'ın Evinin Planı

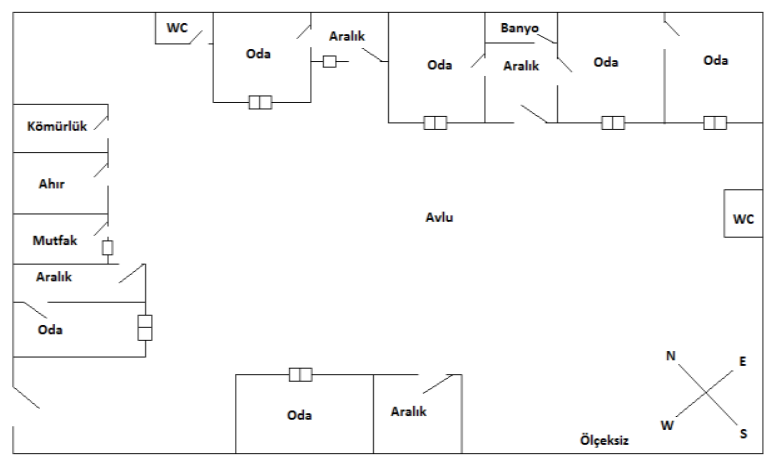

Plan 6. Hilmi KARATEKİ'in Evinin Planı

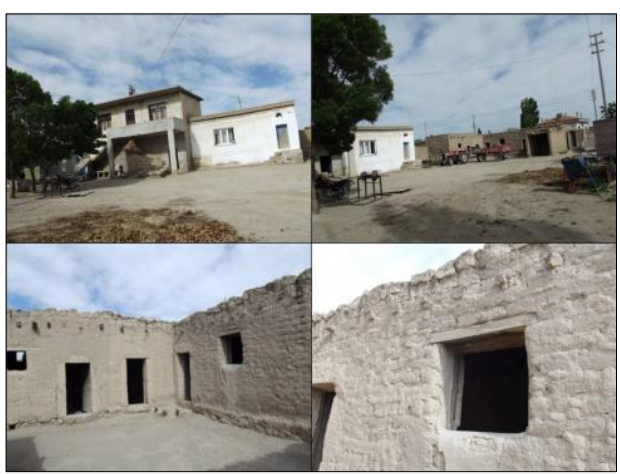

Fig. 7. Ramazan AKCAN'ın Evi (Ağcaşar Köyü, Orta Gelirli)

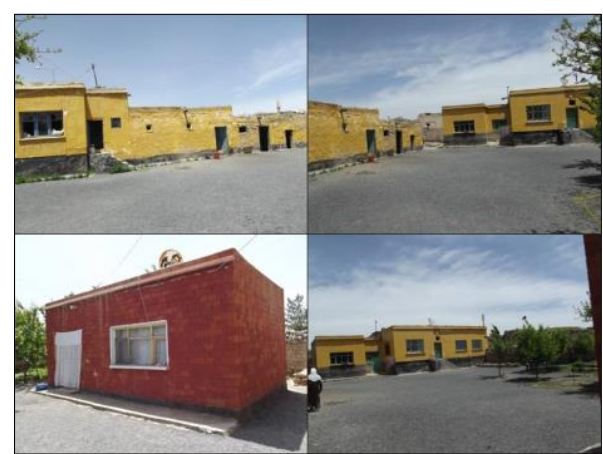

Fig. 8. Hilmi KARATEKİR'in Evi (Yazıhüyük Beldesi, Düşük Gelirli)

Açıkgöz'ün konut ve eklentileri 1990 yılında kerpiçten yapılmıştır. Konutun üzeri hezenlerle (ağaçlarla) örtülü olup, düz toprak çatılıdır (Fig. 9). Konutun giriş kısmı aralığa açılmaktadır. Kayıtlık, konutun bir iç bölümü olup, konut iki odadan oluşmaktadır. Asıl evin batısında evin eklentileri yer almaktadır (Plan 7). Ahır, samanlık, tezeklik, depo (unluk) konutun eklentilerini oluşturmaktadır. Eklentilerin arasında kalan 2 odalı konutta, Mevlüt AÇIKGÖZ'ün kardeşi yaşamaktadır. Konut arazisinin kardeşler arasında ortak kullanılması ve kardeşlerin aynı arazi üzerinde ikamet etmesi, aralarındaki dayanışma ve birlikteliğin devam ettiğini göstermektedir. Kardeşinin oturduğu evin eklentileri, bir ahır avlusuna açılmaktadır.

Benli'nin konutu 1943 yılında kerpiçten yapılmış olup, düz toprak çatılıdır (Fig. 10). Bu kerpiç yapı, inşa edildiği dönemde coğrafi çevrenin konut inşasında daha etkili olduğunu göstermektedir. Alt kat buğday, patates ambarı ve depo olarak kullanılırken, 2. kat oturmaya ayrılmıştır. Garaj, tandır evi ve kümes konutun diğer eklentilerini oluşturmaktadır (Plan 8). Konut ve eklentileri avluyu çevrelemekte olup; evin konumu, evin güneyinden geçen yola göre şekillenmiştir. 


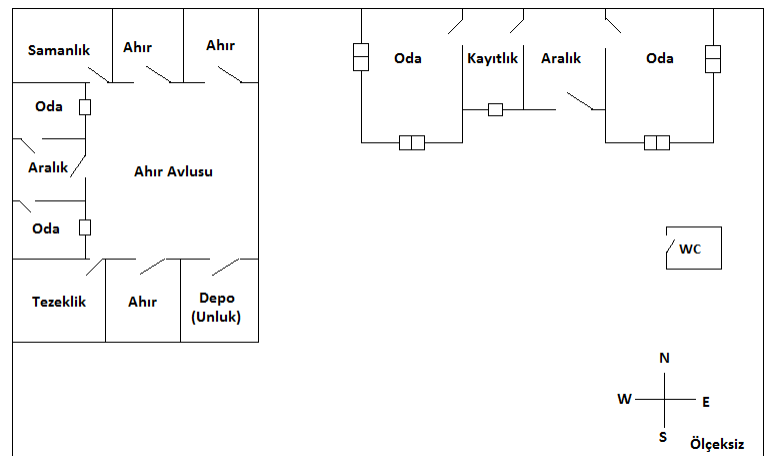

Plan 7. Mevlüt AÇIKGÖZ'ün Evinin Planı
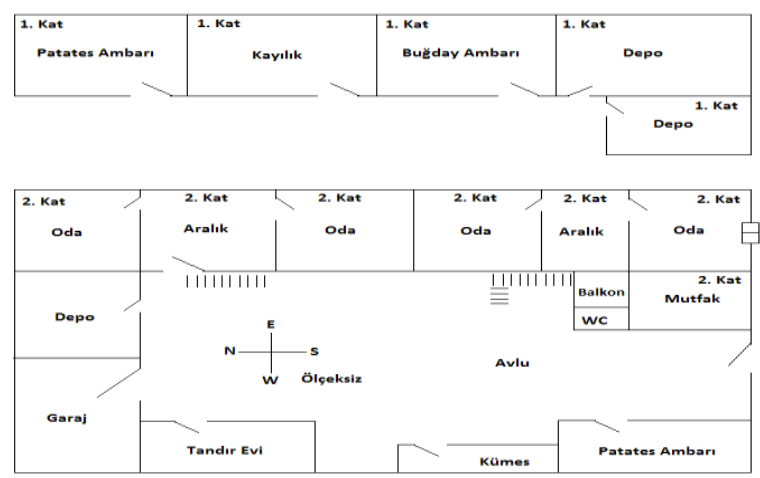

Plan 8. Ramazan BENLI'nin Evinin Planı

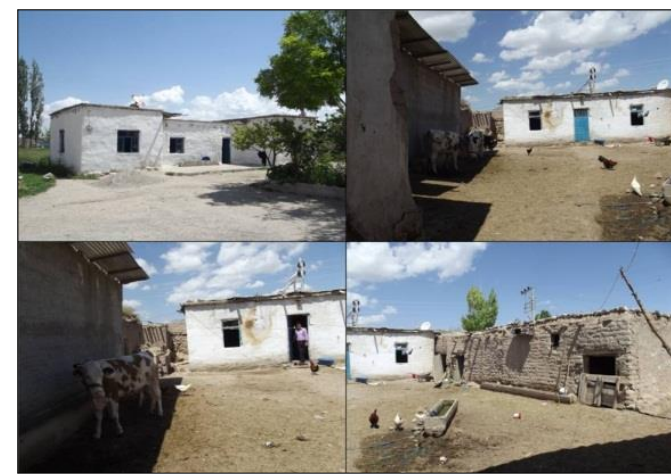

Fig. 9. Mevlüt AÇIKGÖZ'ün Evinin Planı (Bağlama Beldesi, Orta Gelirli)

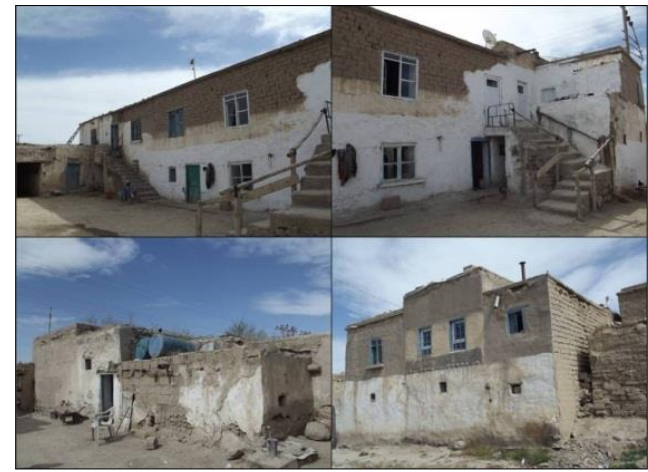

Fig. 10. Ramazan BENLI'nin Evi (Kiledere Beldesi, Düşük Gelirli)

Ozman'ların konutu; 1980 yılında kırmızı tuğladan yapılmıştır. Ahmet ve Mehmet OZMAN, 2. katta yan yana bulunan dairelerde oturmaktadır. Kardeş Yasin OZMAN ise, aynı avlunun doğu köşesinde yer alan evde oturmaktadır (Fig. 11). Kardeşlerin aynı arazi üzerine inşa ettikleri farklı konutlar içinde yaşamaları kendi aralarındaki dayanışma ve işbölümünü göstermektedir. Nitekim yoğun emek isteyen patates ve fasulye tarımında sulama, gübreleme, çapa ve hasat işlerinde kardeşler arasında bir işbölümünün olmaktadır. Ahır, garaj, tandır evi ve tuvalet evin eklentilerini oluşturmaktadır. Konutun ön cephesinin güneş 1sısından daha fazla yararlanmak için güney cepheye baktığı görülmektedir (Plan 9). Araştırma alanlarındaki örneklem seçilen konutlarda görülen tandır evleri geçmişten günümüze bu mekân içinde ekmek yapılmasının bir sonucudur. Günümüzde köy bakkallarında satılan somun ekmekler, köylerde sabah kahvaltısında tüketilmekte, öğle ve akşam yemeklerinde kendi yaptıkları yufka (lavaş) ekmek kullanılmaktadır.

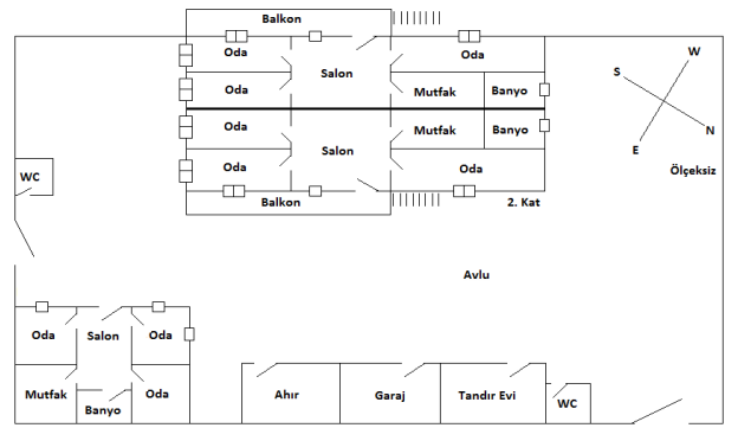

Plan 9. Mehmet, Yasin ve Ahmet OZMAN'ın Evlerinin Planları

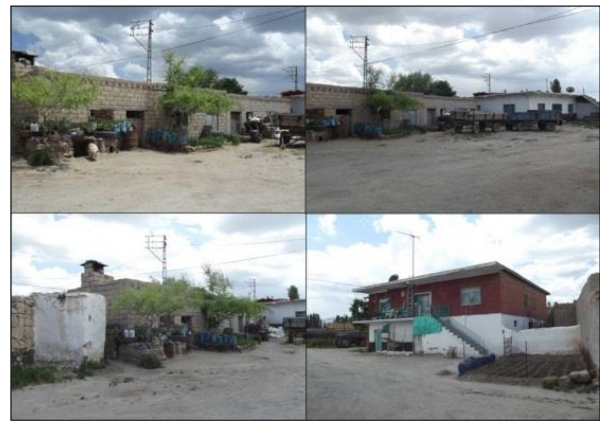

Fig. 11. Mehmet, Yasin ve Ahmet OZMAN'ın Evleri (Hasaköy, Orta Gelirli) 
Özgen'in konutu ve eklentileri briket (bims) yapı malzemesiyle 2000 yılında yapılmış olup, çatısı kırmızı kiremit ile inşa edilmiştir (Fig. 12). Özgen ailesi gibi, Misli Ovası'nda yaşayan ailelerin patates ve fasulye gibi zirai ürünlerden yakın zamanlarda elde ettikleri gelirler ve tasarruflar konutların modern yapı malzemeleri ile yenilenerek hızla değişmesine neden olmuştur. Bu konutun bodrum katı, patates ambarıdır. Kayıtlık, ahır, odunluk, samanlık, garaj ve depo konutun diğer eklentileridir (Plan 10). Kapalı ahırın dışında, avluda üzeri sac örtülü açık ahırda bulunmaktadır. Konutun hâkim rüzgâr yönü olan kuzey cephesine kapalı olacak biçimde ve ön cephesi de güneye bakacak şekilde inşa edildiği görülmektedir.

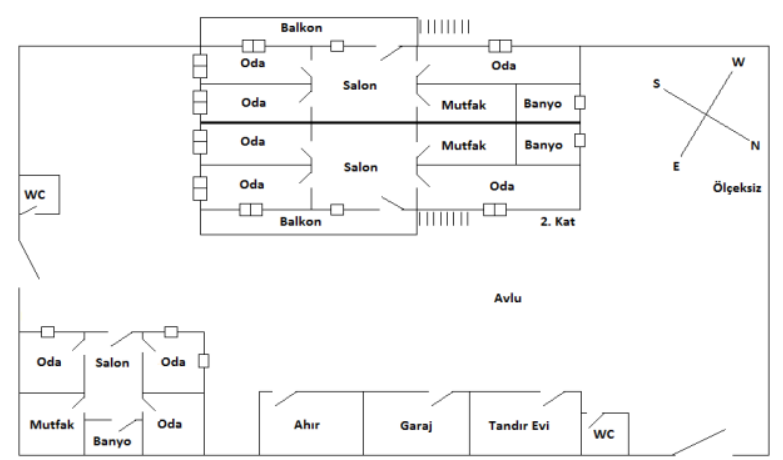

Plan 10. Harun ÖZGEN'in Evinin Planı

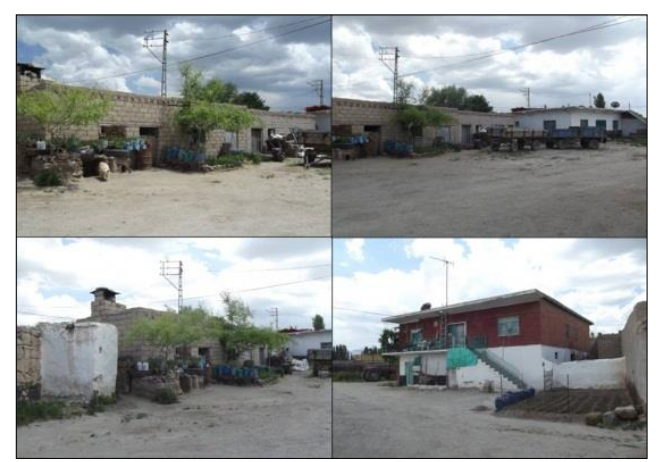

Fig. 12. Harun ÖZGEN'in Evi (Ovacık Beldesi, Gelir Durumu İyi)

Çolak'ın konutu Rumlardan kalma olup, 1881 y1lında taştan yapılmıştır (Fig. 13). Konutun ön cephesi yola (güneye) açılmakta iken, diğer kısımları komşu evlerin duvarları ile bitişik durumdadır. Odalar, kayıtlık ve ahır konutun iç mekânında; we ve mutfak ise avlunun giriş kısmında (dışarıda) yer almaktadır (Plan 11). Araştırma alanındaki tuvaletlerin konut dışına yapılmasında, eskiden kanalizasyon gibi altyapı olanaklarının olmamasının yanı sıra, dinsel nedenlerden dolayı tuvalet mekânlarının kötü kokulu (pis, necis) yer olarak nitelendirilmesi etkili olmuştur. Taş kemer çatılı konutun üzeri toprak ile örtülüdür. Evin yatak odasında, bir gusülhane bulunmaktadır. Evin odalarında gömme dolap, yüklük ve taka'lar bulunmaktadır. Başlangıçta bir Rum evi olmasına rağmen, Türk-İslam gelenekleri ile örtüşen gusülhane, yüklük ve taka gibi konut iç mekânında yapıların olduğu görülmektedir. Ahırların konut içerisine yapılıp, mutfağın konut dışında (avluda) olması, o dönemin güvenlik ve sosyokültürel durumu ile ifade edilebilir.

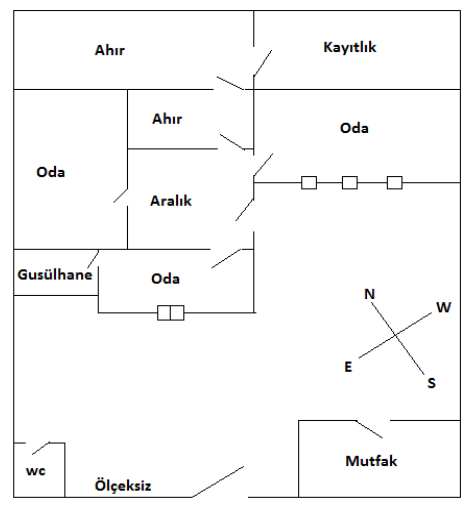

Plan 11. İsmail Çolak'ın Evinin Plan

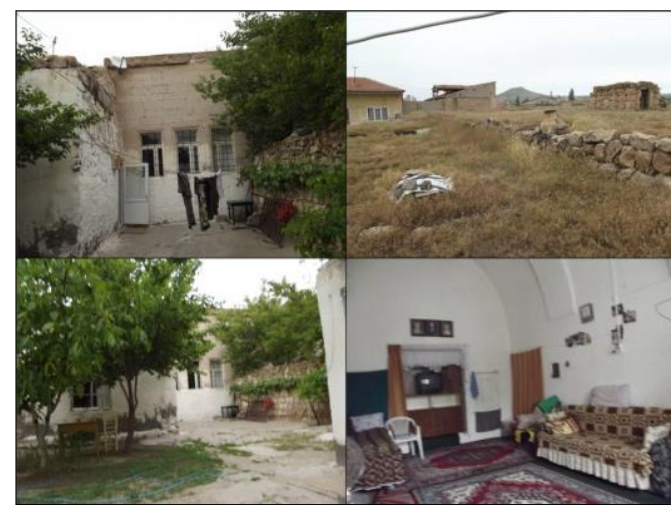

Fig. 13. İsmail Çolak’ın Evi (Derinkuyu, Orta Gelirli)

\section{Sonuç}

Zamana bağlı olarak kırsal peyzajdaki konut tiplerinin evrildiği görülmektedir. Başlangıçta doğal çevre ile sıkı ilişki içerisinde olan kırsal meskenlerin hanelerin gelir durumunun yüksel- 
mesi, ulaşım ve teknolojik imkânlar sonucunda doğal çevreye daha az bağlı kalan modern konutlara dönüştüğü görülmektedir. Başka bir ifadeyle; ailelerin gelir durumu arttıkça konutlarını günün şartlarına göre modern yapı malzemeleri ile yenilendikleri ve yakın çevredeki yapı malzemelerinden bağımsız olarak konutların inşa edildiği görülmektedir. Yakın çevreden toplanan volkanik kayaçlar (ignimbirit), toprak ve saman karışımı kerpiç ve ocaklardan kesilen taşlar yakın bir zamana kadar ovadaki kırsal meskenlerin ana yapı malzemesini oluştururken; günümüzde bu malzemelerin yerini çimento, demir ve alçı gibi modern yapı malzemelerinin aldığı görülmektedir. Ayrıca yöre insanının büyük kentlere (İstanbul vb.) ve Avrupa'ya olan mekânsal hareketliliği, televizyon (dizi) ve internet gibi iletişim araçları, çocukların kentlerde okuması, kent ile olan ekonomik ve sosyal ilişkiler konutların gelenekselden uzaklaşmasında etkili olmaktadır. Bu etkiyi yapılan modern konutlarda görebilmek mümkündür.

Araştırma sahasında yer alan konutların tasarım ve planları üzerinde çevresel etmenler, kültürel unsurlar ve ekonomik faaliyetler gibi birçok faktörün etkili olduğu görülmektedir. Arazinin litolojik yapısı, iklim özellikleri, hane sayısı, gelenekler, inançlar, yapılan tarım ve hayvancılık faaliyetleri konut ve eklentilerinin yapısı, sayıs1, büyüklüğü üzerinde etkili olduğu görülmektedir. Litolojik unsurlar konutu yapı malzemesi (taş, kerpiç vb.) bakımından etkilerken, klimatik faktörlerin evin konumu, kapı ve pencerelerin cephe yönü, duvar kalınlığı, çatı örtüsü ve yönü açısından etkili olduğu anlaşılmıştır. Hidrografik unsurlar taban suyu seviyesi ile konutun zemin ve duvarlardan rutubet alması açısından, bitki örtüsü konutun ara malzemeleri (çatı örtüsü, dolap, pencere, kapı) bakımından etkili olduğu belirlenmiştir. Sosyokültürel unsurlar; evin avlulu olup olmaması, avlu duvarının yüksekliği, gusülhane, oda sayısı gibi iç ve dış mekân tasarımında etkili olduğu fark edilmiştir. Ayrıca aynı avlu içinde ailenin evlenen çocuklarının bir arada oturduğu ve iki üç kardeşin aynı avlu içindeki farklı konutlarda birlikte yaşadıkları görülmüştür. Bu bakımdan, kırsal konutların plan ve tasarımlarında çevresel, sosyokültürel ve ekonomik faktörlerin etkili olduğu bu araştırma alanında görülmüştür.

\section{Yazarın Notu}

$\mathrm{Bu}$ araştırma 2013 yılında Atatürk Üniversitesi Sosyal Bilimler Enstitüsü Beşeri ve İktisadi Coğrafya Anabilim Dalı'nda “Misli Ovasında Mesken Tipleri” konu başlığında yüksek lisans tezi olarak kabul edilmiş olup, tezin sonuçlarının bir bölümünün yeniden düzenlenerek güncellenmesini içermektedir. Haritaların hazırlanmasında teknik destek sağlayan Muhammet Topuz'a ve Emin Toroğlu'na teşekkür ederiz. 


\section{KAYNAKÇA}

Akdemir M. Z. \& Korkmaz E. (2010). "Geleneksel Konut Dokularında Malzemenin Çatı ve Cephe Kuruluşuna Etkileri: Batı Karadeniz Bölgesi Örneği”. 5. Ulusal Çatı \& Cephe Sempozyumu Bildiriler Kitabl (15-16 Nisan). İzmir (2010)129-135.

Atik D. \& Erdoğan N. (2007). "Geleneksel Konut Mimarlığını Etkileyen Sosyo-Külttürel Faktörler. Edirne'de Şinasi Dörtok Evi”. J Sci 8/1 (2007) 21-27.

Avcı S. (1986). Ilıca'da Mesken Tipleri ve Başlıca Sorunlar. Yayımlanmamış Yüksek Lisans Tezi. Atatürk Üniversitesi Sosyal Bilimler Enstitüsü, Erzurum 1986.

Bulut İ. (1988). Yolboyu Köy Yerleşmelerine Bir Örnek: Kars Kümbetli Köyü. Yayımlanmamış Yüksek Lisans Tezi. Atatürk Üniversitesi, Sosyal Bilimler Enstitüsü, Erzurum 1988.

Bulut İ. (2002). "Torul İlçesi’nin Mesken Şekilleri Sorunları ve Çözüm Önerileri”. Gümüşhane: Gümüşhane ve Yöresinin Kalkinma Sетроzуuти (23-25 Ekim). Cilt 2 (2002) 748-760.

Bulut İ. \& Ceylan S. (2012). "Yurtdışı Gurbetçiliğinin Yoğun Olduğu Köylere Bir Örnek: Akçaören Köyü (Altunhisar-Niğde)”. Atatürk Üniversitesi, Sosyal Bilimler Enstitüsü Dergisi 16/1 (2012) 211-228.

Ceylan S. (2013). Misli Ovasında (Niğde) Mesken Tipleri. Yayınlanmamış Yüksek Lisans Tezi. Atatürk Üniversitesi, Sosyal Bilimler Enstitüsü, Erzurum 2013.

Çevik B. \& Tekinel O. (1998). Kırsal Yerleşim Tekniği. Adana 1998.

Davulcu M. (2009). "Sakarya Yöresi Kırsal Yerleşmelerinde Konut Mimarisi ve Ustalık Geleneği Üzerine Bir İnceleme”. Kastamonu Eğitim Dergisi 17/2 (2009) 687-706.

Demirarslan D. (2011). "Eski Bir Bektaşi Yerleşimi: Yörük Köyü’nde Evler ve Odanın Oluşumu”. Gazi Üniv. Türk Kültürü ve Hacı Bektaş Veli Araştırma Merkezi, Türk Kültürü ve Hacı Bektaş Veli Araşstrması 58 (2011) 69-89.

Deniz B. (1992). “Manisa Yöresi Köy Ev Mimarisi”. Arkeoloji-Sanat Tarihi Dergisi V (1992) 17-46.

Dirican R. $\left(1993^{2}\right)$. Să̆llğg Etkileyen Önemli Fiziksel Etmenler ve Bunların Zarar Vermesini Önleme Yöntemleri. Bursa 1993.

Doğanay H. (1989). "Doğu Anadolu Bölgesi’ne Yönelik Toplu Konut Uygulamasının Coğrafi Planlama Esasları: Erzurum Örneği”. Atatürk Üniversitesi Fen-Edebiyat Fakültesi Coğrafya Makaleleri (1989) 115-135.

Eldem S. H. (1975). Türk Evi Plan Tipleri. İstanbul 1975.

Erci B. \& Bulut İ. (1999). "Konutların Fiziksel Özelliklerinin Sosyo-Ekonomik Düzey ve Konut Sağlı̆ı ile İlişkisi”. Sendrom: Aylık Aktüel Tip Dergisi I/II-8 (1999) 114-119.

Erinç S. (1973). “Türkiye: İnsan ve Ortam”. İ.Ü. Coğrafya Enstitüsü Dergisi 18-19 (1973) 1-35.

Gür Ş. Ö. (2000). Doğu Karadeniz Örneğinde Konut Kültürü. İstanbul 2000.

Hayli S. (2001). "Erzincan Ovasında Köy Meskenleri”. Furat Üniversitesi Sosyal Bilimler Dergisi 11/2 (2001) 21-42.

Hutteroth W. D. (1971). “İç Anadolu'da Sosyal Yapının Arazi Bölünmesi ve İskan Üzerine Etkileri”. Eds. E. Tümertekin, F. Mansur \& P. Benetict, İstanbul: Türkiye Coğrafi ve Sosyal Araşttrmalar (1971) 55-87.

Işık Ş. (1992). “Ezine-Bayramiç Çevresinde Kır Meskenleri, İzmir”. Ege Coğrafya Dergisi 6 (1992) 101-117.

Işık B., Akın A., Kuş H., Çetiner İ., Göçer C. \& Arıŏlu N. (1995). Alçı Katkılı Kerpiç Yapı Malzemesine Uygun Mekanize İnşaat Teknolojisinin ve Standartlarmin Belirlenmesi. TÜBITTAK. Proje No: İNTAG TOKİ 622. İstanbul: İTÜ Mimarlık ve Mühendislik Fakültesi.

İzbırak R. (1992). Coğrafi Terimler Sözlüğ̈̈. İstanbul 1992.

İzbırak R. (1996). Türkiye II. İstanbul 1996.

Karpuz H. (1993). Türk-İslam Mesken Mimarisinde Erzurum Evleri. Ankara 1993.

Kaya G. (2005). "Posof Çayı Havzasında Kır Meskenleri”. Atatürk Üniversitesi Sosyal Bilimler Dergisi 5/34 (2005) 137-155.

Kayserili A. \& Altaş N. F. (2010). "Horasan İlçesindeki Kır Meskenlerinin Kültürel Coğrafya Bakış Açısıyla İncelenmesi”. Doğu Coğrafya Dergisi 23 (2010) 81-102.

Korkanç M. (2007). "İgnimbritlerin Jeomekanik Özelliklerinin Yapı Taşı Olarak Kullanmaya Etkisi: Nevşehir Taşı”. Jeoloji Mühendisliği Dergisi 1/31 (2007) 49-60. 
Köse A. (2005). "Türkiye'de Geleneksel Kırsal Konut Planlarında Göçebe Türk Kültürü İzleri”. Afyon Kocatepe Üniversitesi Sosyal Bilimler Dergisi VII/2 (2005) 165-200.

Köse A. (2006). "Balıkesir Örneğinde Geleneksel Kırsal Avlu Duvarı". Afyon: Afyon Kocatepe Üniversitesi Sosyal Bilimler Dergisi VIII/2 (2006) 159-183.

Köse A. (2007). "Balıkesir Çevresinde Geleneksel Kırsal Avlu Peyzajı ve Değişimi”. Doğu Coğrafya Dergisi 18 (2007) 7-38.

Kuban D. (1975). Sanat Tarihimizin Sorunları. İstanbul 1975.

Küçükerman Ö. (1973). Anadolu'daki Geleneksel Türk Evinde Mekân Organizasyonu Açısından Odalar. İstanbul 1973.

Özav L. (2002). "Sivaslı ve Çevresinde Kır Konutları". Afyon Kocatepe Üniversitesi Sosyal Bilimler Dergisi 4/2 (2002) 31-42.

Özbaşaran M., Duru G. \& Kayacan N. (2011). Konut ve Insan: Aşlkl Höyük Deneysel Kerpiç Mimarisi. TÜBITAK. Proje No: 109K030, İstanbul Üniversitesi Prehistorya Anabilim Dalı.

Özden M. Y. (1988). “Çankırı Kuzeyi İle Ilgaz Dağları Arasında Kır Yerleşmeleri İle İlgili Gözlemler”. Ankara Üniversitesi D.T.C.F. Dergisi XXXII/1 (1988) 293-305.

Özgür E. M. (2010). Yerleşme Coğrafyasina Giriş Coğrafya Ders Notları. Ankara 2010.

Özturan Ö. (2010). "Teknolojik Gelişmelerin İç Mekân Biçimlenişine Etkisi”. Tasarımda Genç Bakışlar Sетровуити (26 Ekim). İstanbul 2010.

Rapoport A. (1969). House Form and Culture. London 1969.

Saran N. (1984). Köylerimiz. İstanbul 1984.

Soysal S. (2008). Konut Binalarının Tasarım Parametrelerinde Enerji Tüketim İlişkisi. Yayımlanmamış Yüksek Lisans Tezi. Gazi Üniversitesi Fen Bilimleri Enstitüsü, Ankara 2008.

Tanoğlu A. (1969). Nüfus ve Yerleşme. İstanbul 1969.

Tolun-Denker B. (1977). Yerleşme Coğrafyası: Kır Yerleşmeleri. İstanbul 1977.

Tunçdilek N. (1967). Türkiye İskân Coğrafyası: Kır İskânı. İstanbul 1967.

Tunçdilek N. (1971). “Kır Yerleşmeleri: Köy-Altı Şekilleri”. Eds. E. Tümertekin, F. Mansur \& P. Benetict, Türkiye Coğrafi ve Sosyal Araş̧trmalar (1971) 17-54. İstanbul.

Tunçdilek N. (1984). "Türkiye Köylerinin Yapısal Özelliklerine Toplu Bir Bakış”. İ.Ü. Deniz Bilimleri ve Coğrafya Enstitü Dergisi 1/1 (1984) 23-40.

Tunçdilek N. (1985). Türkiye'de Relief Şekilleri ve Arazi Kullanımı. İstanbul 1985.

Tümertekin E. (1994). Beşeri Coğrafya'ya Giriş. İstanbul 1994.

Utkutuğ G. (2000). Yeni Bin Ylla Girerken Sürdürülebilir Bir Gelecek İçin Ekolojik ve Enerji Etkin Hedefler ile Bina Tasarım ve İşletimi, Ulusal Enerji Verimliliği Kongre Kitabı. Ankara 2000.

Ünal Ç. (1997). "Pasinler'de Geleneksel Kır Meskenleri”. Doğu Coğrafya Dergisi 2 (1997) 271-283.

Yücel T. (1988). “Türkiye'de Kır Yerleşme Tipleri”. Türk Kültürü Dergisi, Yaşar Önen'e Armağan Sayısı (1988) 61-69.

Yüksek İ. (2005). "Kırklareli Geleneksel Konutlarında Pencerelerin Karakteristik Özelliklerine Yönelik Bir Çalışma". Trakya Üniversitesi Fen Bilimleri Dergisi 6/2 (2005) 17-26.

Yüksek İ., Esin T. \& Yıldız A. (2007). "Kırklareli Kırsal Mimarisinde Kullanılan Geleneksel Yapı Malzemeleri: Üretim Şekilleri ve Sürdürülebilirlik Olanakları". Faculty of Engineering \& Architecture Department of Architecture, III. International Sinan Symposium $\left(12^{\text {th }}-13^{\text {th }}\right.$ April) Trakya Üniversitesi, Edirne 2007.

Yüksek İ. \& Esin T. (2008). "Kırklareli Geleneksel Kırsal Mimarisinde Bitkisel Yapı Malzemesi Kullanımı”. 4. Ulusal Yapr Malzemesi Kongresi ve Sergisi (12-14 Kasım). İstanbul 2008.

Zeybekoğlu D. (2005). Edirne Geleneksel Konut Mimarllğın Etkileyen Sosyo-Kültürel Faktörlerin İncelenmesi. Yayımlanmamış Yüksek Lisans Tezi. Trakya Üniversitesi Fen Bilimleri Enstitüsü, Edirne 2005.

Zaman M. (1996). “Tonya (Trabzon) İlçe Merkezinde Mesken Tipleri”. Doğu Coğrafya Dergisi 1 (1996) 495-508.

Zorlu T. \& Sağsöz A. (2010). "Müstakil Konut Sitelerinde Kullanıı Tercihlerine Bağlı Fiziki Müdahaleler: Trabzon Örneği”. METU Journal of The Faculty of Architecture $27 / 2$ (2010) 189-206. 